\title{
CANINE VISCERAL LEISHMANIASIS: STUDY OF METHODS FOR THE DETECTION OF IgG IN SERUM AND ELUATE SAMPLES
}

Fabiano B. FIGUEIREDO(1), Maria F. MADEIRA(2), Lílian D. NASCIMENTO(2), Tuanne R. ABRANTES(1), Eliame MOUTA-CONFORT(2), Sonia Regina L. PASSOS(3) \& Tânia Maria P. SCHUBACH(1)

\begin{abstract}
SUMMARY
The Brazilian Ministry of Health recommends the culling and euthanasia of dogs with a positive serological test for canine visceral leishmaniasis (CVL). In the Municipality of Rio de Janeiro, the technique used for the diagnosis of CVL is the indirect fluorescent antibody test (IFAT), using blood samples eluted on filter paper (eluate). A dog survey was conducted over a period of one year in the region of Carapiá, in order to evaluate the diagnosis of CVL in this region. All animals underwent clinical examination, and blood samples (serum and eluate) were collected for analysis by enzyme immunoassay (ELISA) and IFAT. A skin biopsy was obtained for parasitological examination (culture). A total of 305 animals were studied and Leishmania chagasi was isolated from nine animals. Sensitivity and specificity were $100 \%$ and $96.6 \%$ for ELISA, respectively, $100 \%$ and $65.5 \%$ for IFAT (cut-off at a 1:40 dilution), $100 \%$ and $83.4 \%$ for IFAT (cut-off at a 1:80 dilution), and $22.2 \%$ and $97.0 \%$ for eluate IFAT. In conclusion, ELISA was the best tool for the diagnosis of CVL among the serological techniques tested. The present results suggest the need for a better evaluation of filter paper IFAT as the only diagnostic method for CVL in the Municipality of Rio de Janeiro.
\end{abstract}

KEYWORDS: Leishmania; Dog; Diagnosis; Serological methods; Rio de Janeiro.

\section{INTRODUCTION}

Leishmaniasis is an important zoonosis and is one of the six leading world epidemics ${ }^{29}$. Leishmaniasis is caused by different protozoans of the genus Leishmania and is transmitted to the vertebrate host by insect vectors of the subfamily Phlebotominae ${ }^{19,29}$.

In Brazil, American visceral leishmaniasis (AVL) represents a serious public health problem due to its wide geographic distribution, large number of cases, and severity of its clinical form $\mathrm{s}^{20}$. The epidemiology of AVL in Brazil is eminently rural, but the disease is currently spreading to mid-size and large urban areas such as Palmas (TO), Campo Grande (MS), Belo Horizonte (MG), and Rio de Janeiro (RJ). Leishmania (Leishmania) chagasi (syn. L. infantum) is the etiological agent responsible for the disease, and Lutzomyia longipalpis has been identified as the main transmitting vector ${ }^{12,20}$.

In the wild, reservoirs of Leishmania are foxes (genera Dusicyon and Cerdocyon) and marsupials (genus Didelphis), whereas in urban areas the domestic dog (Canis familiaris) represents the main source of infection for the vector ${ }^{8,19,23,24}$. Therefore, one of the main measures for the control of AVL in Brazil is the identification and culling of seroreactive dogs in endemic areas in order to interrupt the cycle of transmission ${ }^{20}$.
In the municipality of Rio de Janeiro, the technique used for the diagnosis of canine visceral leishmaniasis (CVL) is the indirect fluorescent antibody test (IFAT) using blood samples eluted on filter paper (eluate). Although eluates are used for the serological diagnosis of numerous diseases ${ }^{11,13}$, few studies have compared the use of serum and eluate for the routine diagnosis of leishmaniasis in dogs. Using mathematical models, PALATNIK-DE-SOUSA et al. ${ }^{22}$ demonstrated the inefficacy of eluate IFAT in the control of CVL and the superiority of IFAT and ELISA using serum samples. The Brazilian Ministry of Health currently recommends the use of ELISA for the screening of seroreactive animals and subsequent confirmation by IFAT ${ }^{20}$.

The gold standard for the diagnosis of leishmaniasis is a positive parasitological test ${ }^{5}$. Clinical specimens for the diagnosis of CVL by parasitological examination can be obtained by aspiration of bone marrow, spleen, liver and lymph nodes and, in some cases, by a biopsy of intact $\operatorname{skin}^{15,16}$, lesion, or viscera ${ }^{2,3}$.

In view of the importance of the domestic dog for the maintenance of the transmission cycle of AVL in endemic areas and of discussions regarding the use of eluate samples for its diagnosis, we evaluated the eluate IFAT method used by the Municipal Health Secretary Office of Rio de Janeiro (SMS/RJ) by comparing it with parasitological

Financial Support: Fundação de Apoio à Pesquisa do Rio de Janeiro (FAPERJ).

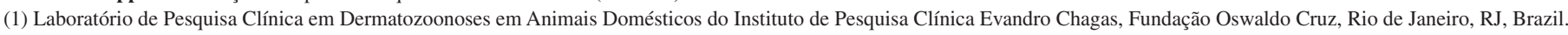

(2) Laboratório de Vigilância em Leishmanioses do Instituto de Pesquisa Clínica Evandro Chagas, Fundação Oswaldo Cruz, Rio de Janeiro, RJ, Brazil.

(3) Laboratório de Epidemiologia Clínica do Instituto de Pesquisa Clínica Evandro Chagas, Fundação Oswaldo Cruz, Rio de Janeiro, RJ, Brazil.

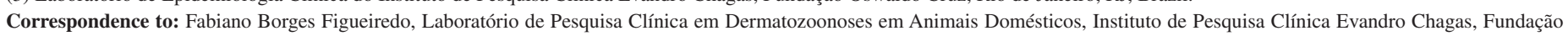

Oswaldo Cruz, Rio de Janeiro, Av. Brasil 4365, Manguinhos, 21045-900 Rio de Janeiro, RJ, Brasil. Tel: +55 21 3865 9536. E-mail: fabiano.figueiredo@ipec.fiocruz.br 
FIGUEIREDO, F.B.; MADEIRA, M.F.; NASCIMENTO, L.D.; ABRANTES, T.R.; MOUTA-CONFORT, E.; PASSOS, S.R.L. \& SCHUBACH, T.M.P. - Canine visceral leishmaniasis: study of methods for the detection of IgG in serum and eluate samples. Rev. Inst. Med. Trop. Sao Paulo, 52(4): 193-6, 2010.

examination (isolation in culture) and serological techniques using serum samples.

\section{MATERIAL AND METHODS}

In 2005, the Municipal Health Secretary Office performed a dog survey in the region of Carapiá, Guaratiba, western region of the Municipality of Rio de Janeiro, which identified 351 dwellings comprising a population of 698 inhabitants and 341 dogs. The survey of CVL in the region was conducted using isolation of the parasite in culture (skin biopsy) and the findings were compared to IFAT and ELISA using serum samples and to IFAT using eluate samples. The last method was performed by the Epidemiology Service of the Municipality of Rio de Janeiro.

The responsible persons of each household visited received detailed information about the study and signed a free informed consent form before agreeing to anamnesis, and before the animals underwent clinical examination and sample collection. The project was approved by the Ethics Committee on the Use of Animals (CEUA-FIOCRUZ-L. 0298-06).

For the collection of skin fragments, the dogs were sedated by intramuscular injection of $10 \mathrm{mg} / \mathrm{kg}$ ketamine hydrochloride plus $0.2 \mathrm{mg} /$ $\mathrm{kg}$ acepromazine. After asepsis and local anesthesia with $2 \%$ lidocaine hydrochloride, a biopsy was obtained from apparently healthy skin on the inner side of the auricle or scapular region of all animals. The tissue fragments were kept in saline containing 1000 IU penicillin, 200 $\mu \mathrm{g}$ streptomycin and $50 \mu \mathrm{g} 5$ '-fluorocytocine per milliliter and stored at $4{ }^{\circ} \mathrm{C}$ for $24 \mathrm{~h}$ for isolation in culture and subsequent isoenzyme characterization according to protocols described in the literature ${ }^{16}$.

For the serological test, a $5 \mathrm{~mL}$ blood sample was collected from each animal by venipuncture after trichotomy with a disposable scalpel, and local antisepsis was performed with $70 \%$ alcohol. The brachial vein was punctured in large dogs and the jugular vein in medium-size and small dogs. The presence of anti-Leishmania IgG antibodies in dog serum was investigated using the Canine Visceral Leishmaniasis IFAT and ELISA kits (Bio-Manguinhos/FIOCRUZ/MS). The following two criteria were adopted for interpretation of the IFAT results: samples presenting fluorescence at dilutions of 1:40, 1:80 or higher were considered to be positive. For ELISA, samples showing readings above the cut-off were considered to be positive according to manufacturer recommendations. For both tests, the same sample was analyzed in duplicate at different times.

Analysis of eluate samples was carried out by the Epidemiology Service of the Municipality of Rio de Janeiro according to the procedures indicated in the manual of the Canine Visceral Leishmaniasis IFAT kit (Bio-Manguinhos/FIOCRUZ/MS).

Sensitivity, specificity, and both positive and negative predictive values were evaluated. The Chi-square test was used for the comparison of proportions. Analyses were performed with the Statistical Package for the Social Science (SPSS), version 11, and the Epi Info 6.04 program, considering a $95 \%$ confidence interval (CI).

\section{RESULTS}

On the basis of the dog census performed over a period of one year, $305(89.4 \%)$ animals of a population of $341 \mathrm{dogs}$ were studied. Thirty-six $(10.6 \%)$ dogs were excluded, mainly because of the lack of adherence of their owners to the study, the absence of a responsible person at the residence, and losses due to the death of some animals between the census in 2005 and the present study.

Leishmania sp. were isolated by culture of intact skin samples from nine animals, corresponding to a prevalence of $3 \%$ (95\% CI: 1.4; 5.7). These species were identified as Leishmania (Leishmania) chagasi by isoenzyme electrophoresis.

Of the 305 samples tested, $19(6.2 \%)$ were positive by ELISA, 111 $(36.4 \%)$ by IFAT (cut-off at a dilution of 1:40), and 58 (19\%) by IFAT (cut-off at a dilution of 1:80).

The accuracy parameters of the tests for the detection of antiLeishmania IgG, using parasitological examination as a reference, demonstrated a better performance of ELISA for the evaluation of dogs infected with Leishmania chagasi (Table 1). Although the sensitivity of IFAT using serum samples was $100 \%$, irrespective of the positivity criterion adopted, specificity was higher at a cut-off dilution of 1:80 $(83.4 \%)$, when compared to the 1:40 dilution (65.5\%) (Table 1). Similarly, the difference in specificity between ELISA $(96.6 \%)$ and IFAT $(83.4 \%)$ was also significant $(p=0 ; 95 \% \mathrm{CI})$. The likelihood ratios for positive results were 29.4 for ELISA, and 2.98 and 6.02 for IFAT at cut-off dilutions of 1:40 and 1:80, respectively. IFAT using eluate samples showed a lower sensitivity (22.2\%) compared to the other tests and a likelihood ratio of 7.4. The other accuracy parameters are shown in Table 1.

\section{DISCUSSION}

In the present study, a dog census was performed using isolation of the parasite in culture as the gold standard for the diagnosis of CVL

Table 1

Performance of ELISA and IFAT for canine visceral leishmaniasis with serum and eluate samples

\begin{tabular}{|c|c|c|c|c|}
\hline & Sensitivity (IC 95\%) & Specificity (IC 95\%) & PPV (IC 95\%) & NPV (IC 95\%) \\
\hline IFAT (Eluate) & $22.2(3.9 ; 59.8)$ & $97.0(94.1 ; 98.5)$ & $18.2(3.2 ; 97.6)$ & $97.6(94.9 ; 98.9)$ \\
\hline IFAT (1:40) & $100(62.8 ; 100)$ & $65.5(59.8 ; 70.9)$ & $8.1(4.0 ; 15.2)$ & $100(97.6 ; 100)$ \\
\hline IFAT (1:80) & $100(62.8 ; 100)$ & $83.4(78.6 ; 87.4)$ & $15.5(7.8 ; 27.9)$ & $100(98.1 ; 100)$ \\
\hline ELISA & $100(62.8 ; 100)$ & $96.6(93.7 ; 98.3)$ & $47.4(25.2 ; 70.5)$ & $100(98.3 ; 100)$ \\
\hline
\end{tabular}

IC (confidence interval); IFAT (indirect fluorescence antibody test); ELISA (enzyme immunoassay); PPV (positive predictive value); NPV (negative predictive value). 


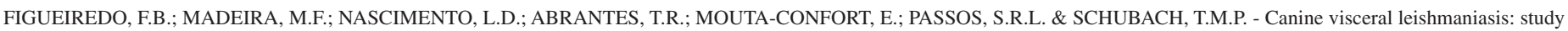
of methods for the detection of IgG in serum and eluate samples. Rev. Inst. Med. Trop. Sao Paulo, 52(4): 193-6, 2010.

and comparing it to serological methods (IFAT and ELISA using serum samples and IFAT using eluate samples).

Parasitological confirmation by culture of intact skin fragments from seroreactive dogs has been shown to be successful in clinical practice for the diagnosis of CVL. In two studies conducted in the Municipality of Rio de Janeiro, MADEIRA et al..$^{16,17}$ isolated Leishmania from 18/20 and from 31/39 animals, respectively, using skin fragments obtained from dogs euthanized because of a suspicion of CVL for parasitological confirmation. In another study, the same authors reported a rate of isolation of $78.7 \%$ when skin samples from 394 dogs were evaluated ${ }^{15}$. A similar percentage ( $83 \%$ ) has been reported by BARROUIN-MELO et $a l{ }^{2}$ who analyzed spleen samples from seroreactive dogs. These results demonstrate that intact skin fragments can be used as the target sites for the parasitological confirmation of CVL based on mild intervention, with sensitivity close to that observed for the culture of organs of the phagocytic-mononuclear system. One advantage of this technique is that it is applied easily. However, operational difficulties are encountered by public health authorities in implementing this procedure in routine practice.

Culling of seroreactive dogs from AVL-endemic areas for the control of the disease is a polemic subject because of the disagreement among investigators regarding the accuracy of the tests currently employed for this purpose $e^{1,7,27,28}$. There is no scientific evidence demonstrating the impact of dog culling on human infection. Another widely discussed aspect is the cut-off value used to define positive or negative IFAT reactions ${ }^{6}$. In AVL endemic areas, the BRAZILIAN MINISTRY OF HEALTH $^{20}$ recommends the culling and euthanasia of dogs that are reactive in the IFAT assay at dilutions of 1:40 or higher. In the present study, the sensitivity of the IFAT assay was the same for the two cutoff dilutions used (1:40 and 1:80). On the other hand, specificity was significantly higher when a cut-off dilution of 1:80 was defined. This discordance might be due to the overlapping geographic endemicity of AVL with American tegumentary leishmaniasis and sporotrichosis, which occur at some localities in the Municipality of Rio de Janeiro, favoring low-affinity cross-reactivity that is detected at low dilutions. RIBEIRO et al. ${ }^{25}$ observed reactivity in $14.3 \%$ of serum samples from dogs with sporotrichosis at dilutions of 1:40. These results suggest that, at least in areas of low prevalence, a more appropriate cut-off would be at a dilution of 1:80. With respect to the performance of ELISA and IFAT using serum samples, the results regarding the accuracy of the tests are conflicting. FERREIRA et al. ${ }^{10}$ observed 52\% and 64\% specificity and $96 \%$ and $72 \%$ sensitivity for ELISA and IFAT, respectively. OLIVEIRA et $a .^{21}$ demonstrated $90 \%$ sensitivity and $100 \%$ specificity for ELISA and $40 \%$ sensitivity and $98.6 \%$ specificity for IFAT. However, LIRA et $a l .{ }^{14}$ observed no significant difference between the two tests. Although no differences in the sensitivity of the techniques were observed in the present study, specificity was significantly higher for ELISA and the positive predictive values for the IFAT were very low. In addition, there was a 29.4 times higher chance that a positive ELISA result is a true positive result, a value higher than that observed for IFAT. The use of intact parasites and whole parasite extracts in serological tests may result in cross-reactions with other Leishmania species and with Trypanosoma cruzi, Ehrlichia canis and Sporothrix schenckii ${ }^{18,25,26}$. Therefore, the specificity of $96.6 \%$ and likelihood ratio of 29.4 obtained for ELISA seem to be relevant, especially when considering that the samples analyzed were obtained from dogs living in areas that are also endemic for diseases of other etiologies and that the species isolated from seropositive dogs was characterized as L. chagasi.

The sensitivity of IFAT using blood dried on filter paper and then processed and analyzed at the Epidemiology Service of Rio de Janeiro was much lower than that obtained for IFAT and ELISA using serum samples. This observation was confirmed in a subsequent study carried out in the same region, in which $34.9 \%$ of positive dogs were identified by serum IFAT among 146 dogs that tested seronegative by IFAT using blood samples collected on filter paper ${ }^{9}$. Although the serum and eluate samples were processed and analyzed at different laboratories, the results obtained suggest that IFAT using samples collected on filter paper may not be adequate for epidemiological surveys. Aspects related to sample collection, transport and storage may explain, in part, the low performance of eluate samples when compared to serum samples. On the other hand, the accuracy of ELISA suggests that this diagnostic method would be best suited for campaigns of visceral leishmaniasis control, reducing two major problems. The first is related to the number of infected dogs that remain after culling of seropositive animals and that are not detected by other tests, and the second refers to the unnecessary sacrifice of dogs due to the large number of false-positive IFAT reactions in serum. BRAGA et $a l .{ }^{4}$ demonstrated that up to 2.85 times more seropositive dogs are detected by ELISA using serum samples than by IFAT testing of eluate samples.

The present results suggest that the method used in the Municipality of Rio de Janeiro for the diagnosis of CVL should be better evaluated and that the filter paper IFAT might be replaced with ELISA. In addition, the results demonstrate the superiority of ELISA over IFAT and that ELISA might be indicated for epidemiological surveys. Comparison of these results with those obtained by the Epidemiology Service of Rio de Janeiro (IFAT testing of eluates) also demonstrates the superiority of ELISA, showing $100 \%$ sensitivity and $96.6 \%$ specificity.

\section{RESUMO}

\section{Leishmaniose visceral canina: avaliação de métodos para detecção de IgG em amostras de soro e eluato}

O Ministério da Saúde recomenda a eutanásia de cães sororreatores como controle da leishmaniose visceral canina (LVC). No Município do Rio de Janeiro, a técnica utilizada para o diagnóstico da LVC é o teste de imunofluorescência indireta (IFI), utilizando amostras de sangue eluídas em papel de filtro (eluato). Um levantamento, durante um ano, foi conduzido na região de Carapiá, a fim de avaliar o diagnóstico da LVC nesta região. Todos os animais foram submetidos a exame clínico e coleta de sangue (soro e eluato) para realização do ensaio imunoenzimático (ELISA) e imunofluorescência indireta (IFI). Biópsia de pele foi obtida para o exame parasitológico (cultura). Foram avaliados $305(89,4 \%)$ animais de uma população de 341 cães e Leishmania chagasi foi isolada de nove animais. A sensibilidade e especificidade do ELISA foram de $100 \%$ e $96,6 \%$, na IFI (ponto de corte $1: 40$ ) de $100 \%$ e $65,5 \%$, na IFI (ponto de corte $1: 80$ ) de $100 \%$ e $83,4 \%$ e na IFI (eluato) de $22,2 \%$ e $97,0 \%$, respectivamente. A partir dos resultados obtidos podemos concluir que entre as técnicas sorológicas empregadas, o teste de ELISA apresentou-se como a melhor ferramenta para o diagnóstico da LVC. Os resultados sugerem a necessidade de uma melhor avaliação do teste de IFI realizada com eluato, como único método de diagnóstico para LVC no município do Rio de Janeiro. 
FIGUEIREDO, F.B.; MADEIRA, M.F.; NASCIMENTO, L.D.; ABRANTES, T.R.; MOUTA-CONFORT, E.; PASSOS, S.R.L. \& SCHUBACH, T.M.P. - Canine visceral leishmaniasis: study of methods for the detection of IgG in serum and eluate samples. Rev. Inst. Med. Trop. Sao Paulo, 52(4): 193-6, 2010.

\section{REFERENCES}

1. Alves WA, Bevilacqua PD. Reflexões sobre a qualidade do diagnóstico de leishmaniose visceral canina em inquéritos epidemiológicos: o caso da epidemia de Belo Horizonte, Minas Gerais, Brazil, 1993-1997. Cad Saúde Pública. 2004;20:259-65.

2. Barrouin-Melo SM, Larangeira DF, de Andrade Filho FA, Trigo J, Julião FS, Franke CR, et al. Can spleen aspirations be safely used for the parasitological diagnosis of canine visceral leishmaniosis? A study on assymptomatic and polysymptomatic animals. Vet J. 2006;171:331-9.

3. Barrouin-Melo SM, Larangeira DF, Trigo J, Aguiar PH, dos Santos WL, Pontes-deCarvalho L. Comparison between splenic and lymph node aspirations as sampling methods for the parasitological detection of Leishmania chagasi infection in dogs. Mem Inst Oswaldo Cruz. 2004;99:195-7.

4. Braga MD, Coêlho IC, Pompeu MM, Evans TG, MacAullife IT, Teixeira MJ, et al. Controle do calazar canino: comparação dos resultados de um programa de eliminação rápida de cães sororreagentes por ensaio imuno-enzimático com outro de eliminação tardia de cães sororreagentes por teste de imunofluorescência indireta de eluato de papel filtro. Rev Soc Bras Med Trop. 1998;31:419-24.

5. Chouihi E, Amri F, Bouolimi N, Siala E, Selmi K, Zallagua N, et al. Cultures on NNN medium for the diagnosis of leishmaniasis. Pathol Biol (Paris). 2009;57:219-24.

6. Dantas-Torres F, De Brito ME, Brandão-Filho SP. Seroepidemiological survey on canine leishmaniasis among dogs from an urban area of Brazil. Vet Parasitol. 2006;140:5460 .

7. De Paula AA, da Silva AV, Fernandes O, Jansen AM. The use of immunoblot analysis in the diagnosis of canine visceral leishmaniasis in an endemic area of Rio de Janeiro. J Parasitol. 2003;89:832-63.

8. Deane LM, Deane MP. Observações preliminares sôbre a importância comprovativa do homem, do cão e da rapôsa (Lycalopex vetulus) como reservatórios da Leishmania donovani, em área endêmica de calazar, no Ceará. O Hospital. 1955;48:61-70.

9. Figueiredo FB, Madeira MF, Menezes RC, Pacheco RS, Pires MQ, Furtado MC, et al. Efficacy of an indirect immunofluorescence test in the diagnosis of canine leishmaniosis. Vet J. 2009; In press. (Epub ahead of print).

10. Ferreira E de C, de Lana M, Carneiro M, Reis AB, Paes DV, da Silva ES, et al. Comparison of serological assays for the diagnosis of canine visceral leishmaniasis in animals presenting different clinical manifestations. Vet Parasitol. 2007;146:235-41

11. Herrera R, Cabrera MV, Garcia S, Gilart M. IgM antibodies to dengue virus in dried blood on filter paper. Clin Chim Acta. 2006;367:204-6.

12. Lainson R, Rangel EF. Lutzomyia longipalpis and the eco-epidemiology of American visceral leishmaniasis, with particular reference to Brazil: a review. Mem Inst Oswaldo Cruz. 2005;100:811-27.

13. Lima VL, Rangel O, Andrade VR, Silveira NY, Oliveira SS, Figueiredo LT. Dengue: sero-epidemiological survey and virological surveillance in Campinas, São Paulo, Brazil. Cad Saúde Pública. 2007;23:669-80.

14. Lira RA, Cavalcanti MP, Nakazawa M, Ferreira AG, Silva ED, Abath FG, et al. Canine visceral leishmaniosis: a comparative analysis of the EIE-leishmaniose-visceralcanina-Bio-Manguinhos and the IFI-leishmaniose-visceral-canina-Bio-Manguinhos kits. Vet Parasitol. 2006;137:11-6.

15. Madeira MF, Figueiredo FB, Pinto AG, Nascimento LD, Furtado M, Mouta-Confort E, et al. Parasitological diagnosis of canine visceral leishmaniasis: is intact skin a good target? Res Vet Sci. 2009;87:260-2.
16. Madeira MF, Schubach AO, Schubach TM, Pereira SA, Figueiredo FB, Baptista C. Post mortem parasitological evaluation of dogs seroreactive for Leishmania from Rio de Janeiro, Brazil. Vet Parasitol. 2006;138:366-70.

17. Madeira MF, Schubach AO, Schubach TM, Leal CA, Marzochi MCA. Identification of Leishmania (Leishmania) chagasi isolated from healthy skin of symptomatic and asymptomatic dogs seropositive for leishmaniasis in the municipality of Rio de Janeiro, Brazil. Braz J Infect Dis. 2004;8:440-4

18. Mancianti F, Pedonese F, Poli A. Evaluation of dot enzyme-linked immunosorbent assay (dot-ELISA) for the serodiagnosis of canine leishmaniosis as compared with indirect immunofluorescence assay. Vet Parasitol. 1996;65:1-9.

19. Marzochi MCA, Marzochi KBF. Tegumentary and visceral leishmaniasis in Brazil: emerging anthropozoonosis and possibilities for their control. Cad Saúde Pública. 1994;10:359-75.

20. Ministério da Saúde. Manual de vigilância e controle da leishmaniose visceral. Brasília: Ministério da Saúde; 2006.

21. Oliveira LS, Julião FS, Souza VMM, Freitas DS, Souza BMPS, Paula BTA, Aguiar PHP, et al. A utilização da imunofluorescência indireta no diagnóstico de rotina da leishmaniose visceral canina e suas implicações no controle da doença. Ciên Animal Bras. 2005;6:41-7.

22. Palatnik-de-Sousa CB, Batista-de-Melo LM, Borja-Cabrera GP, Palatnik M, Lavor CC Improving methods for epidemiological control of canine visceral leishmaniasis based on a mathematical model. Impact on the incidence of the canine and human disease. An Acad Bras Cienc. 2004,76:583-93.

23. Palatnik-de-Sousa CB, dos Santos WR, Franca-Silva JC, Da Costa RT, Reis AB, Palatnik $\mathrm{M}$, et al. Impact of canine control on the epidemiology of canine and human visceral leishmaniasis in Brazil. Am J Trop Med Hyg. 2001;65:510-7.

24. Paranhos-Silva M, Freitas LA, Santos WC, Grimaldi G Jr, Pontes-de-Carvalho LC. A cross-sectional serodiagnostic survey of canine leishmaniasis due to Leishmania chagasi. Am J Trop Med Hyg. 1996;55:39-44.

25. Ribeiro FC, Schubach AO, Mouta-Confort E, Schubach TM, de Fátima Madeira M, Marzochi MC. Use of ELISA employing Leishmania (Viannia) braziliensis and Leishmania (Leishmania) chagasi antigens for the detection of IgG and IgG1 and IgG2 subclasses in the diagnosis of American tegumentary leishmaniasis in dogs. Vet Parasitol. 2007;148:200-6.

26. Roffi J, Carrie J, Garre MT, Dedet JP. Immunoenzymatic detection of human African trypanosomiasis using dried blood samples. Bull Soc Pathol Exot Filiales. 1980;73:6774

27. Scalone A, de Luna R, Oliva G, Baldi L, Satta G, Vesco G, et al. Evaluation of the Leishmania recombinant K39 antigen as a diagnostic marker for canine leishmaniasis and validation of a standardized enzyme-linked immunosorbent assay. Vet Parasitol. 2002;104:275-85.

28. Silva AV, Paula AA, Cabrera MA, Carreira JC. Leishmaniasis in domestic dogs epidemiological aspects. Cad Saude Publica. 2005;21:324-8.

29. World Health Organization. Leishmaniasis. Fourteenth Programme Report. UNDP/World Bank/Special Programme for Research and Training in Tropical Diseases (TDR). Tropical Diseases Research Progress 1977-1998. Geneva: World Health Organization; 1999. p. 1-6.

Received: 3 November 2009

Accepted: 28 June 2010 